\title{
ПОНЯТИЕ И ПРИНЦИПЫ НАЛОГОВОГО КОНТРОЛЯ, ЕГО МЕСТО В СИСТЕМЕ ФИНАНСОВОГО КОНТРОЛЯ В РОССИЙСКОЙ ФЕДЕРАЦИИ
}

\author{
(c) 2020 Казанкова Татьяна Николаевна \\ кандидат педагогических наук, доцент кафедры публичного права \\ Самарский государственный экономический университет, Россия, Самара \\ E-mail: tatianaok78@yandex.ru \\ (C) 2020 Говорина Ольга Александровна \\ магистрант \\ Самарский государственный экономический университет, Россия, Самара \\ E-mail: olgagovorina@mail.ru
}

В данной статье представлен анализ сущности налогового контроля как элемента финансового контроля, проанализированы различные варианты толкования термина «налоговый контроль», а также детально рассмотрены общеправовые принципы, на которых базируется налоговый контроль.

Ключевые слова: финансовый контроль, налоговый контроль, государственные финансы, финансовое планирование.

Главным звеном управления финансами государства и условием плодотворной работы системы финансов и экономики является финансовый контроль. В настоящее время в системе финансов, финансовый контроль рассматривается как одна из основных контрольных функций государства.

От налоговых поступлений зависит объем доходов консолидированного бюджета РФ, поскольку они являются основным источником бюджета всех уровней. Консолидированный бюджет складывается из налогов, сборов, страховых взносов, которые взимаются с юридических и физических лиц, поскольку важность налогов при формировании государственных фондов играет основную роль налогового контроля в системе государственного финансового контроля.

Финансовый контроль можно определить, как систему действий, направленных на проверку финансов и связанных с ними вопросов по регулированию деятельности субъектов хозяйствования, а также по управлению её с применением специально утверждённых способов, методов и форм его организации [3].

Вместе с тем, данный вид контроля настолько многогранен и охватывает обширный спектр сфер, что внутри него можно выделить виды и формы. Одним из самых обширных его видов является налоговой контроль, который безусловно служит важнейшим направлением финансового контроля. Это обусловлено приори- тетностью для государства своевременного и в полном объеме поступления налогов, сборов, а также страховых взносов в бюджетные фонды [3].

Существует множество трактовок понимания налогового контроля - это связано с большой историей данного вида административного управления на общество со стороны государства.

В соответствии с п. 1 ст. 82 НК РФ [1], под налоговым контролем следует понимать осуществляемую уполномоченными органами деятельность по контролю за соблюдением требований, предусмотренных законодательством о налогах и сборах, в порядке, установленном НК РФ.

Отечественные ученые и практики считают, что указанное законодателем определение понятия налогового контроля, носит слишком обобщенный, а потому недостаточно полный характер, поскольку в нем не раскрываются присущие ему специфические признаки [2].

В связи с отмеченным, в научной и специальной литературе можно выделить значительное количество различных авторских трактовок данного понятия.

Автор - экономист А.В.Брызгалин под налоговым контролем понимает совокупность приемов и способов руководства компетентных органов, которые призваны обеспечивать соблюдение требований, установленных в налоговом законодательстве, правильность исчисления, полноту и своевременность внесения в бюджет или внебюджетный фонд соответствующих платежей. 
С точки зрения И.И.Кучерова налоговый контроль выступает в качестве одного из важнейших направлений финансового контроля. Пытаясь дать определение понятию налогового контроля, И.И.Кучеров ставит акцент исключительно на его превентивном воздействии на поведение подлежащих контролю субъектов и умалчивает о выполняемой им пресекательной функции, которая играет достаточно существенную роль.

По мнению Ю.А.Крохиной, понятие налогового контроля необходимо рассматривать в узком и широком смыслах. Так, в широком понимании налоговый контроль, как утверждает указанный автор, представляет собой совокупность мер государственного регулирования, которые призваны обеспечивать национальную экономическую безопасность, а также соблюдение фискальных интересов, и имеют своей целью осуществление нашим государством эффективной политики в финансовой сфере. В узком смысле понятие налоговый контроль выступает в качестве контроля компетентных органов, действующих от имени и в интересах государства, за правомерностью и обоснованностью действий в процессе установления, взимания налогов, сборов.

Авторы М.В.Романовскй и О.В.Рублевская предлагают определять налоговый контроль посредством указания на систему мероприятий, которые связаны: с проверкой законности, эффективности и целесообразности действий, осуществляемых при формировании денежных фондов на всех уровнях управления и власти в части налоговых доходов государства; с выявлением резервов при увеличении налоговых поступлений в бюджет а также улучшением налоговой дисциплины. Кроме того, указанные авторы отмечают, что налоговый контроль также представляет собой совокупность приемов и методов, которые используются органами власти и управления и призваны обеспечивать исполнение законодательства о налогах и сборах, правильность исчисления, полноту и своевременность поступления обязательных платежей в бюджет [2].

Учёные-экономисты сходятся во мнении, что налоговый контроль служит, прежде всего, для обеспечения полноты, гарантии и своевременности поступления налогов и сборов в бюджет, соблюдение необходимых мер налогового законодательства, а также применение адми- нистративных механизмов ответственности для лиц, которые нарушили установленные законодательством правовые механизмы. Также необходимо отметить, что все авторы отмечают юридический аспект вышеназванной контрольной деятельности, подчеркивая, что она регулируется соответствующими правовыми нормами, предусмотренными законодательством государства [3].

Налоговый контроль подразумевает под собой реализацию задачи пополнения государственного бюджета на любом уровне. Налоговый контроль дисциплинирует налогоплательщиков на своевременную и полную уплату обязательных платежей.

Налоговый контроль носит властный характер, поскольку он проявляется в реализации полномочий субъектов налогового администрирования по контролю за уплатой налогов и других обязательных платежей юридическими лицами и физическими лицами, в соответствии с действующим налоговым законодательством. Налоговый контроль основан на особенностях налоговых правоотношений, на фискальной функции налогов, а также зачастую на нежелании налогоплательщиков уплачивать налоги.

Проанализировав все определения можно обозначить и выделить наиболее общую и в то же время детально проработанную формулировку. Так, налоговый контроль можно обозначить, как установленную законодательством совокупность приемов и методов деятельности уполномоченных органов, которая в свою очередь обеспечивает соблюдение плательщиками законодательства о налогах и сборах, в частности порядка исчисления, полноты и своевременности уплаты налогов, сборов, страховых взносов в бюджет, а также во внебюджетные фонды.

Налоговый контроль - это не просто контроль над полным и своевременным исполнением обязательства по уплате налогов. В широком смысле, налоговый контроль - это контроль за реализацией налогового законодательства, при этом мониторинг соблюдения законодательства является общей функцией государства, которая распространяется на все сферы общественных отношений. Контролируя соблюдение закона в целом и налогового законодательства в частности, государство выступает в качестве субъекта, равноудаленного от всех сторон налогового правоотношения, и выступает в качестве своего рода арбитра в споре между налогоплательщи- 
ком и налоговым органом.

Контроль надзорных органов многогранен и включает в себя определённые аспекты:

1. Налоговый контроль - это основополагающая часть финансового контроля и существенная часть налогового механизма. Контрольно-надзорные действия и механизмы пронизывают всю систему налогообложения, абсолютно все налоговые группы плательщиков на всей территории государства. Налоговый контроль охватывает всю экономику, таким образом обеспечивая соблюдение правил бухгалтерского учета и отчетности, законодательных актов и базовых основ налогообложения.

2. Налоговый контроль - определенным образом скомпонованная система мер по контролю за исполнением законодательства в сфере налоговых правоотношений, проводимая уполномоченными органами посредством учета плательщиков, налоговых проверок, мониторинга, опроса плательщиков и других лиц, проверки данных учета и отчетности, анализа информации об использовании электронных денег в качестве оплаты за товары (работы, услуги), имущественные права, осмотра движимого и недвижимого имущества, помещений и территорий, где могут находиться данные объекты, подлежащие налогообложению или используемые для извлечения дохода (прибыли), и в других формах, предусмотренных налоговым и иным законодательством.

Как и любой другой вид правоприменительной деятельности, контроль в сфере налогообложения базируется на определенной совокупности принципов, которые являются своего рода правовой базой, определяющей эффективное выполнение органами налогового контроля своих прямых функций. Этими принципами должны руководствоваться уполномоченные органы в процессе реализации ими контрольных мероприятий [3].

Прежде всего это такие принципы, которые свойственны всем отраслям права:

1. Принцип законности определяет, что лицо должно уплачивать только те налоги и сборы, которые установлены законом, соответственно обязательные платежи не основанные на законе, не могут считаться юридически установленными.

2. Принцип равенства выражается в чётком определении правового статуса. Все субъекты хозяйствования равны между собой и в одинаковой степени несут ответственность за нарушения закона. Обязательные платежи, не могут иметь дискриминационного характера, а также различно применяться в зависимости от социальных, расовых, национальных, религиозных и других факторов. Кроме того не допустимо применение различных ставок и льгот для отдельных категорий налогоплательщиков в зависимости от формы собственности, происхождения капитала и гражданства физических лиц.

3. Принцип всеобщности. Данный принцип предполагает, что определенные обязанности, предусмотренные налоговым законодательством, устанавливаются, по общему правилу, для всего круга лиц.

4. Принцип гласности подразумевает открытость и доступность для субъектов налоговых правоотношений получение от всех государственных органов полной и достоверной информации.

5. Принцип ответственности подразумевает неотвратимость наступления ответственности, предусмотренную законодательством, к лицу, совершившему правонарушение. В ходе налогового контроля происходит полный финансовый аудит бухгалтерии организаций и если будет установлено наличие правонарушения, то виновные лица непременно понесут ответственность.

6. Принцип защиты прав. Правовая защита субъектов хозяйствования должна быть гарантирована абсолютно на всех этапах функционирования налоговых отношений, в том числе и при проведении мероприятий контрольного характера. Субъекты хозяйствования, в отношении которых проводится налоговый контроль, могут обжаловать действия налоговых органов, либо отдельных инспекторов, а также ненормативноправовые акты уполномоченных органов на любом этапе осуществления ими контрольных действий. Данный принцип также отражается в том, что у организации или физического лица в ходе проведения налогового контроля, есть право не исполнять неправомерные, по их мнению, требования должностных лиц или уполномоченных органов.

Налоговый контроль как один из видов государственного финансового контроля может и должен осуществляться по таким направлениям как:

- проверка исполнения налогоплательщиками обязанностей, связанных с необходимо- 
стью их постановки на налоговый учет;

- проверка правильности ведения бухгалтерского (налогового) учета, своевременность исполнения обязанностей по предоставлению налоговых деклараций и достоверности тех сведений, которые в них содержатся;

- проверка порядка исполнения организациями и физическими лицами лежащих на них обязанностей, связанных с исчислением и уплатой налогов, сборов, страховых взносов;

- контроль за деятельностью налогового органа, который ранее проводил налоговую проверку в случае проведения повторной выездной налоговой проверки и т.д.

Формами проведения налогового контроля являются: учет организаций и физических лиц; налоговые проверки; получение объяснений плательщиков; осмотр территорий, помещений, документов и предметов проверяемых лиц; налоговый мониторинг; другие, предусмотренные законодательством о налогах и сборах, формы.

В качестве предмета налогового мониторинга выступают правильность исчисления, полнота и своевременность уплаты налогов и сборов, а также страховых взносов организациями и физическими лицами. Сущность налогового мониторинга состоит в том, что организация в добровольном порядке в режиме реального времени открывает налоговому органу доступ к информации, формирующейся в рамках ведения бухгалтерского и налогового учета, для сверки налоговым органом электронных сведений бухгалтерской базы контролируемой организации со сведениями, имеющимися в распоряжении у налогового органа. В отношении налогоплательщиков - физических лиц не может проводиться данная форма налогового контроля [4].

Значение института налогового мониторинга, по мнению налоговых органов, состоит в следующем:

- создание механизма заблаговременного налогового разъяснения на основании проведенного анализа;

- обеспечение прозрачности правоприменительной деятельности в области законода- тельства о налогах и сборах;

- значительное улучшение восприятия инвесторами делового климата;

- повышение возможности прогноза поступления налоговых платежей;

- своевременное выявление пробелов и коллизий в российском налоговом законодательстве;

- сокращение затрат, связанных с проведением налоговых проверок, издержек судебного характера в связи с уменьшением количества налоговых споров;

- повышение уровня правовой культуры налогоплательщиков [4].

Таким образом, налоговый контроль за уплатой налогов, сборов, страховых взносов призван усовершенствовать порядок исчисления и перечисления таковых.

Подводя итог всему отмеченному выше, можно сделать вывод о том, что под налоговым контролем с точки зрения российского законодателя следует понимать осуществляемую уполномоченными органами деятельность по контролю за соблюдением требований, предусмотренных законодательством о налогах и сборах, в порядке, установленном НК РФ.

Налоговый контроль реализуется посредством применения специфических форм и методов воздействия и имеет своей целью финансовое обеспечение тех социально-экономических задач, которые стоят перед государством и муниципальными образованиями.

Налоговый контроль как одна из функций государства - это система общественных отношений в сфере финансово-экономической деятельности налогоплательщиков, направленная на обеспечение соблюдения налогового законодательства. Особую роль налоговый контроль играет при возникновении необходимости стабилизации финансовой системы, придании устойчивости бюджетным отношениям, соблюдении финансовой дисциплины, как предпосылок для надлежащего исполнения налоговых обязательств перед государством физическими и юридическими лицами.

\section{Библиографический список}

1. Налоговый кодекс Российской Федерации (НК РФ) (в ред. от 01.04.2020 N 102-Ф3)

2. Попов А.П., ИвашоваЕ.Ю. Понятие и отличительные особенности налогового контроля как вида государственного финансового контроля // Теоретические и экспериментальные исследования в современной науке. - 2019.- С. 318-325. 
3. Протас В.В. Понятие и принципы налогового контроля, его место в системе финансового контроля // Научно-практические исследования. - 2020. -№ 3-4 (26).- С. 28-30.

4. Русакова К.В. Налоговый контроль в форме налогового мониторинга // Бухгалтерский учёт, анализ, аудит и налогообложение: проблемы и перспективы.-2019.-С. 151-154. 